\title{
Purification and Characterization of Two Forms of DNA Polymerase $a$ from Mouse FM3A Cells: A DNA Polymerase $a$-Primase Complex and a Free DNA Polymerase $a$
}

\author{
Takemi Enomoto, Masashi Suzuki, Mikiko Takahashi, Katsumi \\ Kawasaki, Yoshinari Watanabe ${ }^{1}$, Kyosuke Nagata ${ }^{2}$, \\ Fumio Hanaoka and Masa-atsu Yamada
}

Department of Physiological Chemistry, Faculty of Pharmaceutical Sciences, University of Tokyo, 7-3-1, Hongo, Bunkyo-ku, Tokyo 113, 1Department of Biochemistry I, Fukui Medical School, Matsuoka, Fukui 910-11 and 2Department of Molecular Genetics, National Institute of Genetics, Mishima, Shizuoka 411, Japan

\begin{abstract}
Two forms of DNA polymerase $\alpha, \alpha 1$ and $\alpha 2$, have been partially purified from mouse FM3A cells by discriminating one form from the other on the basis of the association of primase activity. The primase activity in the most purified a1 fraction co-sedimented with the DNA polymerase activity in a glycerol gradient, and almost no primase activity was detected in the most purified $\alpha 2$ fraction. The primase activity associated with DNA polymerase $a$ was assayed indirectly by measuring ATP-dependent DNA synthesis with poly (dT) as template. Characterization of the assay system was performed with the purified $a 1$. The system was absolutely dependent on the presence of ATP and a divalent cation. $\mathrm{Mn}^{2+}$ was much more effective than $\mathrm{Mg}^{2+}$, and 5-fold higher activity was observed with $\mathrm{Mn}^{2+}$ than with $\mathrm{Mg}^{2+}$ at their optimal concentrations. The primase activity assayed by the above system showed sensitivity to $\left(\mathrm{NH}_{4}\right)_{2} \mathrm{SO}_{4}$ very similar to that of free primase reported by Tseng and Ahlem (J. Biol. Chem. 258, 9845-9849, 1983). The activity was inhibited by more than $50 \%$ by $20 \mathrm{mM}\left(\mathrm{NH}_{4}\right)_{2} \mathrm{SO}_{4}$.

$\alpha 1$ and $\alpha 2$ were very similar as DNA polymerases in their sensitivity to several inhibitors and their preference for template-primers, except that $a 1$ had a slightly greater preference for poly $(\mathrm{dT}) \cdot(\mathrm{rA})_{10}$ than $\alpha 2 \mathrm{did}$. The major difference between the two forms was observed in their $S$ values, 8.2 and 6.4 $\mathrm{S}$ for $\alpha 1$ and $\alpha 2$, respectively.
\end{abstract}

Mammalian cells contain three major classes of DNA polymerases, $\alpha, \beta$, and $\gamma$. Among these polymerases, DNA polymerase $a$ has been suggested to be involved in DNA replication of mammalian cells (24). Many studies of DNA polymerase $a$ isolated from various mammalian cells and tissues have indicated the existence of multiple forms of the enzyme, which differ in their chromatographic behavior and in

Abbreviations used: araCTP, 1- $\beta$-D-arabinofuranosylcytosine triphosphate; NEM, N-ethylmaleimide; PMSF, phenylmethylsulfonyl fluoride. 
sedimentation coefficients. We have also observed that HeLa cells or their isolated nuclei contain two forms of DNA polymerase $a$ which differ in binding affinity to DNA or chromatin $(13,14,17)$. Furthermore, it has been suggested by using a salttreated nuclear system that the form that has higher binding affinity to chromatin is responsible for the synthesis of Okazaki fragments $(3,4)$. However, more critical experiments are necessary to assess the physiological significance of the existence of two forms of DNA polymerase $\alpha$ and to confirm the roles of the enzymes in the processes of DNA replication.

In prokaryotes, genetic analysis and development of in vitro replication systems have permitted functional analysis of many enzymes and proteins participating in DNA replication. The analogous approaches have not yet been well developed in eukaryotes. In recent years we have tried to isolate temperature-sensitive or drugresistant mutants related to DNA replication from mouse FM3A cells and have already isolated several mutants $(11,19,27)$. In addition, we have isolated several enzymes and protein factors such as DNA-dependent ATPases $(18,23)$ and DNA polymerase $\alpha$ stimulating factors $(8,9)$ from FM3A cells. These cells are a good source for the isolation of enzymes and protein factors related to DNA replication because it is possible to obtain a large amount of $S$ phase accumulated cells grown in the abdominal cavity of the mouse (6). Therefore, we have concentrated our efforts on the purification of two forms of DNA polymerase $\alpha$ from FM3A cells, but we have not succeeded in separating clearly the two forms by ion exchange column and DNA-cellulose column chromatographies.

Recently it has been observed in a variety of eukaryotic cells that one form of DNA polymerase $\alpha$ is associated with primase activity $(2,5,12,15,16,20,22,25,26,28)$, providing an effective means to distinguish subspecies of DNA polymerase $\alpha$. In this report, we have separated and partially purified two forms of DNA polymerase $\alpha$ from FM3A cells on the basis of the association of primase activity with one of the forms and compared their properties as DNA polymerases. In addition, we have characterized de novo synthesis primed by the primase associated with a DNA polymerase $a$ on poly(dT) as template.

\section{MATERIALS AND METHODS}

Materials. $\quad\left[{ }^{3} \mathrm{H}\right] \mathrm{dATP}$ and $\left[{ }^{3} \mathrm{H}\right] \mathrm{dTTP}$ were purchased from Amersham (Buckinghamshire, England). Unlabeled deoxyribonucleoside triphosphates were from Boehringer Mannheim (West Germany). AraCTP, NEM, and PMSF were obtained from Sigma (St. Louis, U.S.A.). Sodium bisulfite and aphidicolin were purchased from Wako Chemicals (Osaka). Antipain was kindly supplied by Dr. H. Umezawa (Inst. Microb. Chem., Tokyo). Bovine serum albumin (fraction V) was obtained from Seikagaku Kogyo (Tokyo). Yeast alcohol dehydrogenase and alkaline phosphatase were obtained from Worthington (New Jersey, U.S.A.). Poly(dA), poly(dT), poly[d(A-T)], $(\mathrm{rA})_{10},(\mathrm{dA})_{12-18}$, and $(\mathrm{dT})_{12-18}$ were purchased from P-L Biochemicals (Milwaukee, U.S.A.). Single-stranded DNA-cellulose was prepared essentially according to the method of Alberts and Herrick with slight modification as described previously (17). Activated DNA was prepared as described previously (1).

Cell. FM3A cells $\left(1 \times 10^{6}\right)$ were injected into the abdominal cavity of a ddY mouse. On the 5th day after inoculation, cells were synchronized in $\mathrm{S}$ phase by intraperitoneal injection of $100 \mu \mathrm{g}$ of 5-fluoro-2'-deoxyuridine and harvested as described previously (6). The cells were stored at $-80^{\circ} \mathrm{C}$ until use. 
Assay for DNA polymerase $\alpha$ activity. The standard reaction mixture (total volume $30 \mu$ l) contained $20 \mathrm{mM}$ Tris- $\mathrm{HCl}, \mathrm{pH} 8.0,3.3 \mathrm{mM}$ 2-mercaptoethanol, $5 \mathrm{mM} \mathrm{MgCl}_{2}$, $0.2 \mathrm{mg} / \mathrm{ml}$ bovine serum albumin, $100 \mu \mathrm{M}$ each of dATP, dCTP, and dGTP, $50 \mu \mathrm{M}\left[{ }^{3} \mathrm{H}\right]-$ dTTP $(0.1 \mathrm{Ci} / \mathrm{mmol})$, and $500 \mu \mathrm{g} / \mathrm{ml}$ activated calf thymus DNA. Incubation was carried out for $30 \mathrm{~min}$ at $37^{\circ} \mathrm{C}$ in a plastic immunological microtitration tray. The reaction mixture was transferred onto a Whatman DE81 filter paper disk and the disk was washed by the method of Lindall et al. (10).

Assay for primase activity. The standard reaction mixture (total volume $30 \mu \mathrm{l}$ ) contained $20 \mathrm{mM}$ Tris- $\mathrm{HCl}, \mathrm{pH} 8.0,3.3 \mathrm{mM}$ 2-mercaptoethanol, $0.2 \mathrm{mg} / \mathrm{ml}$ bovine serum albumin, $2 \mathrm{mM}$ ATP, $2 \mathrm{mM} \mathrm{MnCl}_{2}, 100 \mu \mathrm{M}\left[{ }^{3} \mathrm{H}\right] \mathrm{dATP}(0.1 \mathrm{Ci} / \mathrm{mmol})$, and $42 \mu \mathrm{g} / \mathrm{ml}$ poly(dT). Incubation was carried out for $30 \mathrm{~min}$ at $37^{\circ} \mathrm{C}$. The reaction was terminated by chilling the reaction mixture to $0^{\circ} \mathrm{C}$ and by adding $0.2 \mathrm{ml}$ of $0.15 \mathrm{M}$ sodium pyrophosphate, $0.3 \mathrm{ml}$ of $1 \mathrm{mg} / \mathrm{ml}$ carrier DNA, and $2 \mathrm{ml}$ of $5 \%$ TCA containing $1 \%$ sodium pyrophosphate. The TCA-insoluble materials were collected on a Whatman GF/C glass-fiber filter. The filter was washed 5 times with $3 \mathrm{ml}$ of cold $5 \%$ TCA-1\% sodium pyrophosphate and 2 times with ethanol, and dried. The radioactivity was measured with a liquid scintillation counter.

Glycerol gradient centrifugation. Two hundred microliters of sample was loaded on $4.8 \mathrm{ml}$ of $15-35 \%$ glycerol gradient in a medium containing $20 \mathrm{mM}$ potassium phosphate buffer, $\mathrm{pH} 7.5,0.3 \mathrm{M} \mathrm{KCl}, 300 \mu \mathrm{g} / \mathrm{ml}$ bovine serum albumin, $0.1 \mathrm{mM} \mathrm{Na}{ }_{3}$ EDTA, $1 \mathrm{mM}$ 2-mercaptoethanol, $0.25 \mathrm{mM}$ PMSF, and $10 \mathrm{mM}$ sodium bisulfite. Centrifugation was performed for $14.1 \mathrm{~h}$ at $258,000 \times \mathrm{g}$ at $4^{\circ} \mathrm{C}$. Fractions were collected from the bottom of the tube.

Buffers. Buffer 1 contained $20 \mathrm{mM}$ potassium phosphate, pH 7.5, $0.1 \mathrm{mM} \mathrm{Na}{ }_{3}$ EDTA, $1 \mathrm{mM}$ 2-mercaptoethanol, $0.25 \mathrm{mM}$ PMSF, and $10 \mathrm{mM}$ sodium bisulfite. Buffer 2 contained all the components of buffer $1,20 \%$ ethylene glycol, and $0.01 \%$ Triton X-100. Buffer 3 was the same as buffer 2 except that Tris- $\mathrm{HCl}, \mathrm{pH} 8.1$, was used instead of potassium phosphate, pH 7.5. Buffer 4 was the same as buffer 2 except that the concentration of ethylene glycol was reduced to $10 \%$.

\section{RESULTS}

Purification of two forms of DNA polymerase $\alpha$. All operations were carried out at $0-4^{\circ} \mathrm{C}$. A frozen stock of $5 \times 10^{10} \mathrm{FM} 3 \mathrm{~A}$ cells was thawed, suspended in $400 \mathrm{ml}$ of buffer 1 which contained $2 \mu \mathrm{g} / \mathrm{ml}$ antipain, and sonicated 4 times for $10 \mathrm{~s}$ each with $20 \mathrm{~s}$ intervals by a Branson sonifier model $185(40 \mathrm{~W})$. The sonicate was made $0.3 \mathrm{M}$ in $\mathrm{KCl}$ by the addition of $1 / 10$ volume of buffer 1 containing $3.3 \mathrm{M} \mathrm{KCl}$. Extraction was performed for $30 \mathrm{~min}$ with stirring and followed by centrifugation for $1 \mathrm{~h}$ at $105,000 \times \mathrm{g}$. The supernatant was loaded on a DEAE-cellulose column $(500 \mathrm{ml}$; $4.2 \times 36 \mathrm{~cm}$ ) equilibrated with $0.3 \mathrm{M} \mathrm{KCl}$ in buffer 1 . The flow-through fractions were combined and dialyzed against $50 \mathrm{mM} \mathrm{KCl}$ in buffer 2 after the addition of Triton X-100 at a final concentration of $0.01 \%$. The dialyzate was loaded on a second DEAE-cellulose column $(250 \mathrm{ml} ; 4.2 \times 18 \mathrm{~cm})$ equilibrated with $50 \mathrm{mM} \mathrm{KCl}$ in buffer 2 . The column was washed with 2.5 bed volumes of the same buffer, and the proteins adsorbed to the column were eluted with 2.5 bed volumes of $0.4 \mathrm{M} \mathrm{KCl}$ in buffer 2. DNA polymerase $\alpha$ and primase activities were recovered in the $0.4 \mathrm{M}$ $\mathrm{KCl}$-eluate.

The active fractions were combined and dialyzed against buffer 2 containing $0.1 \mathrm{M} \mathrm{KCl}$. The dialyzate was loaded on a phosphocellulose column $(70 \mathrm{ml} ; 2 \times$ 
$22 \mathrm{~cm}$ ) equilibrated with $0.1 \mathrm{M} \mathrm{KCl}$ in buffer 2 . The column was washed with 2.5 bed volumes of the same buffer and eluted with $560 \mathrm{ml}$ of a linear gradient of $\mathrm{KCl}$ from 0.1 to $0.6 \mathrm{M}$ in buffer 2. As shown in Fig. 1, DNA polymerase $a$ was eluted as a broad peak extending from 0.3 to $0.5 \mathrm{M} \mathrm{KCl}$, and the primase activity was eluted at about $0.37 \mathrm{M} \mathrm{KCl}$, forming a rather sharp peak. We designated the DNA polymerase $\alpha$ activity associated with primase activity as $\alpha 1$ and the activity free from primase activity as $\alpha 2$. The two activities were pooled separately as indicated in Fig. 1 and dialyzed against $0.05 \mathrm{M} \mathrm{KCl}$ in buffer 2 . Each dialyzate was loaded separately on DEAE-cellulose columns $(\alpha 1,25 \mathrm{ml}, 1.2 \times 22 \mathrm{~cm} ; \alpha 2,40 \mathrm{ml}, 1.5 \times 22 \mathrm{~cm})$ equilibrated with $0.05 \mathrm{M} \mathrm{KCl}$ in buffer 2 . The columns were washed with 2 bed volumes of the above buffer and eluted with 8 bed volumes of a linear gradient of $\mathrm{KCl}$ from 0.05 to $0.5 \mathrm{M}$ in buffer 2. As shown in Fig. 2, $\alpha 1$ and $\alpha 2$ were eluted from the columns at 0.16 and $0.21 \mathrm{M} \mathrm{KCl}$, respectively. The cross-contaminated activities in the $a 1$ and $a 2$ fractions from the phosphocellulose column were further separated at this stage. The active fractions were pooled as indicated in Fig. 2 and dialyzed against $0.05 \mathrm{M}$ $\mathrm{NaCl}$ in buffer 3 . The dialyzates were loaded on single-stranded DNA-cellulose columns $(\alpha 1,16.5 \mathrm{ml}, 1.9 \times 5.7 \mathrm{~cm} ; \alpha 2,40 \mathrm{ml}, 1.5 \times 22 \mathrm{~cm})$ which were equilibrated with $0.05 \mathrm{M} \mathrm{NaCl}$ in buffer 3 . The columns were washed with 3 bed volumes of the above buffer and eluted with 8 bed volumes of a linear gradient of $\mathrm{NaCl}$ from 0.05 to $0.4 \mathrm{M}$ in buffer 3 . Bovine serum albumin was added at a concentration of $200 \mu \mathrm{g} / \mathrm{ml}$ in the elution buffer so as to stabilize the enzyme activity. The $a 1$ and $a 2$ activities were eluted from the columns at about $0.15 \mathrm{M} \mathrm{NaCl}$. A portion of the peak fractions

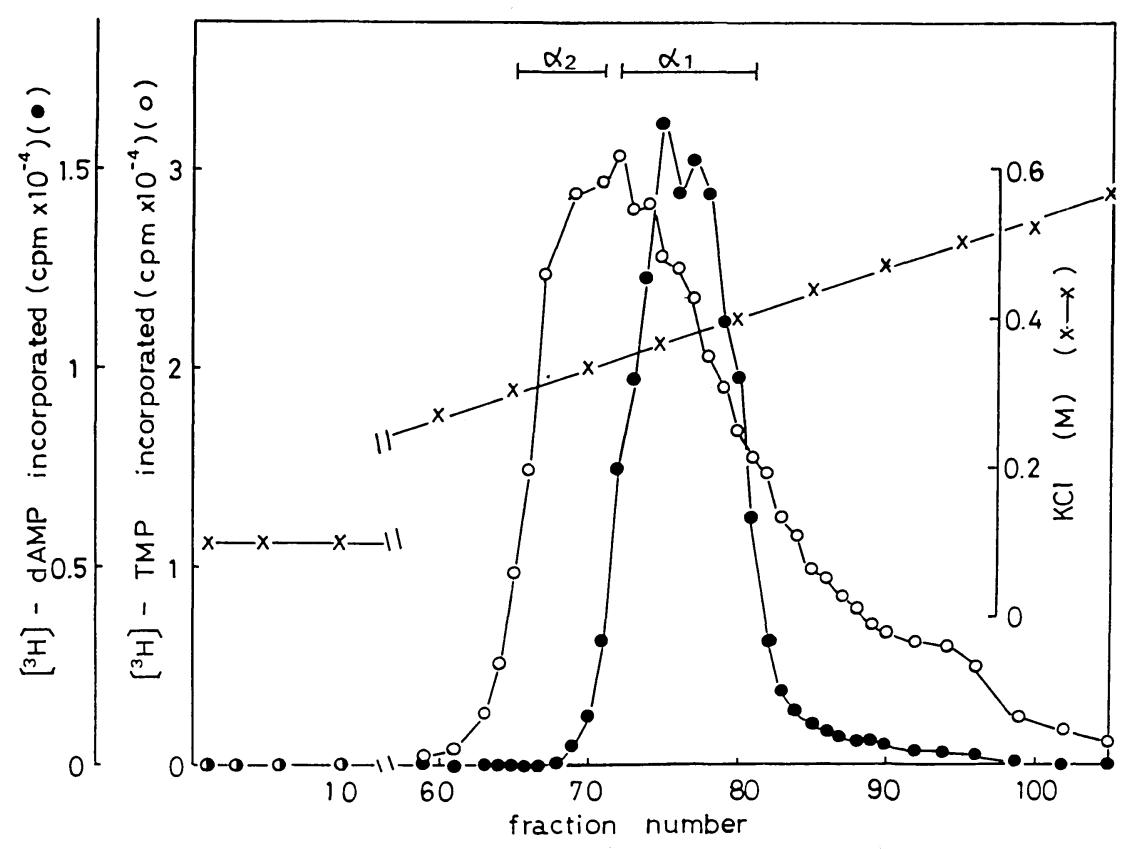

Fig. 1. Phosphocellulose column chromatography. The second DEAE-cellulose column fraction was chromatographed as described in the test. Aliquots of the fractions were assayed for DNA polymerase $a(\bigcirc)$ and primase (๑) activities as described. 

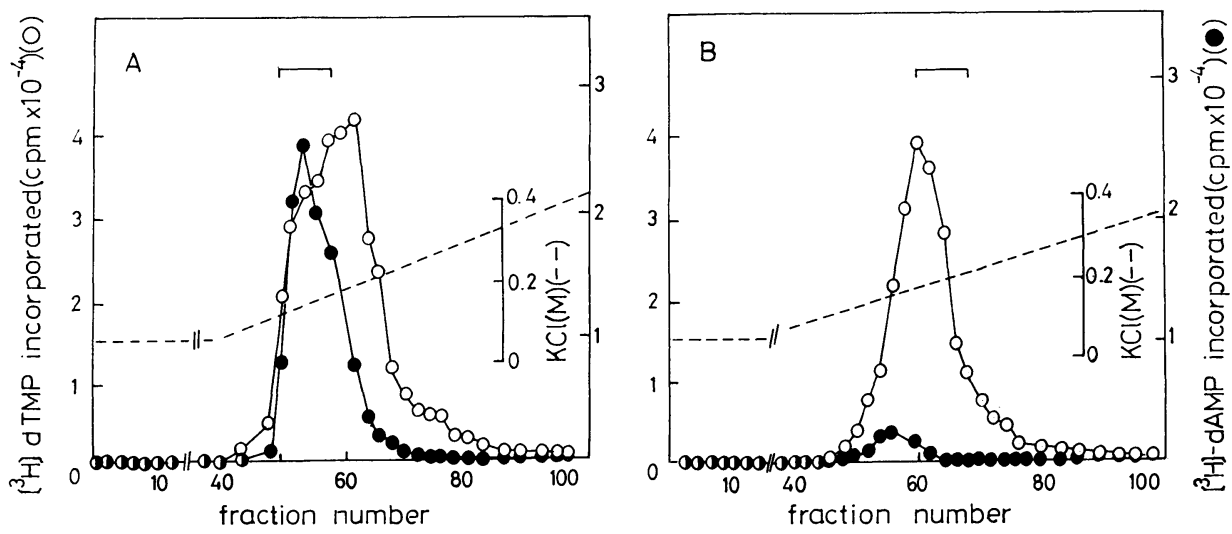

Fig. 2. DEAE-cellulose column chromatography. a1-rich and a2-rich fractions of the phosphocellulose column as indicated in Fig. 1 were chromatographed separately as described in the text. Aliquots of the fractions were assayed for DNA polymerase $a(\bigcirc)$ and primase (O) activities as described. (A) $a 1$, (B) $a 2$.

of each activity was pooled and dialyzed against $0.05 \mathrm{M} \mathrm{NaCl}$ in buffer 1 containing $50 \%$ glycerol. The dialyzates were stored at $-80^{\circ} \mathrm{C}$ until use. Another portion of the peak fractions of each activity was pooled and dialyzed against $0.1 \mathrm{M} \mathrm{KCl}$ in buffer 4 . The dialyzates were adsorbed to small phosphocellulose columns and concentrated by stepwise elution with $0.6 \mathrm{M} \mathrm{KCl}$ in buffer 4 . The peak fractions were pooled and a portion was layered on the top of a glycerol gradient. Centrifugation was performed as described under Materials and Methods. As shown in Fig. 3, $a 1$ and $a 2$ sedimented
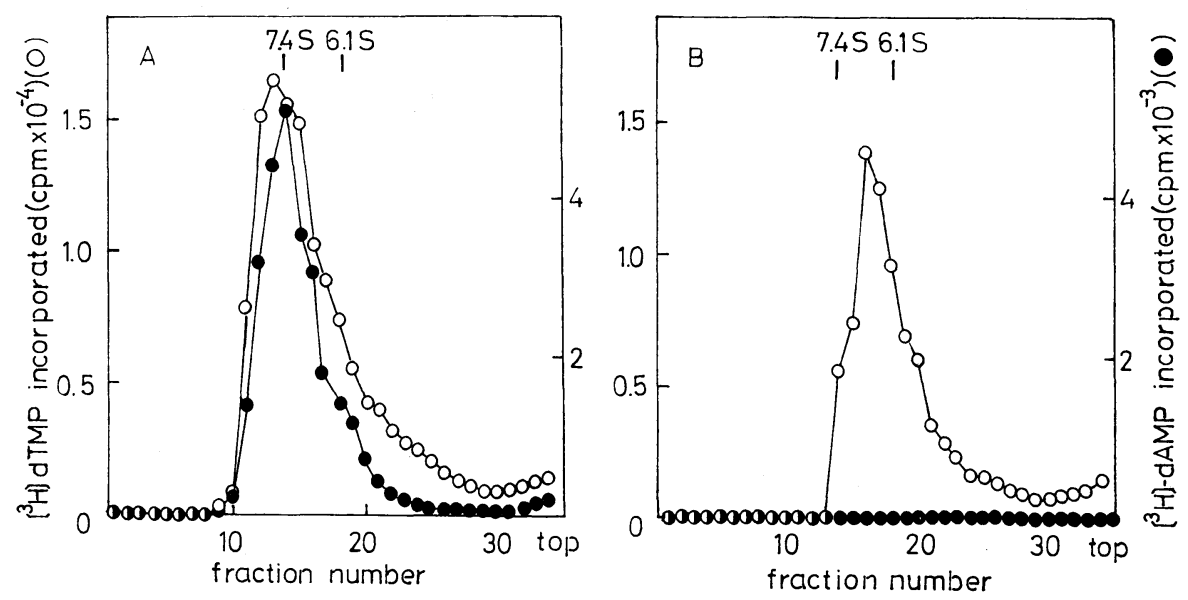

Fig. 3. Glycerol gradient centrifugation of purified $a 1$ and $a 2$. The DNA-cellulose column fractions of $\alpha 1$ and $\alpha 2$ were concentrated and sedimented through glycerol gradients as described in the text. Aliquots of the fractions were assayed for DNA polymerase $\alpha(\bigcirc)$ and primase (O) activities as described. The protein markers run in a parallel gradient were yeast alcohol dehydrogenase (7.4 S) and bacterial alkaline phosphatase (6.1 S). (A) $\alpha 1$, (B) $\alpha 2$. 
TABlE 1. Purification of DNA POlymerase $\alpha 1$ AND $a 2$ From FM3A Cells

\begin{tabular}{lccccccc}
\hline \multirow{2}{*}{ Purification Step } & \multicolumn{3}{c}{ DNA Polymerase $\alpha$ Activity } & \multicolumn{3}{c}{ Primase Activity } \\
\cline { 2 - 8 } & $\begin{array}{c}\text { Protein } \\
\text { (mg) }\end{array}$ & $\begin{array}{c}\text { Total Act. } \\
\text { (units) }\end{array}$ & $\begin{array}{c}\text { Sp. Act. } \\
\text { (units/mg) }\end{array}$ & $\begin{array}{c}\text { Yield } \\
(\%)\end{array}$ & $\begin{array}{c}\text { Total Act. } \\
\text { (units) }\end{array}$ & $\begin{array}{c}\text { Sp. Act. } \\
\text { (units/mg) }\end{array}$ & $\begin{array}{c}\text { Yield } \\
(\%)\end{array}$ \\
\hline Crude Extract & 5817 & 29195 & 5.0 & 100 & 4957 & 0.8 & 100 \\
1st DEAE-cellulose & 4173 & 28273 & 6.8 & 97 & 2214 & 0.5 & 45 \\
2nd DEAE-cellulose & 1114 & 27256 & 24.5 & 93 & 2010 & 1.8 & 41 \\
\hline \multicolumn{1}{c}{ (11 } & & & & & & & \\
Phosphocellulose & 94 & 19940 & 211 & 68 & 2725 & 29 & 55 \\
DEAE-cellulose & 21 & 7903 & 364 & 27 & 2207 & 102 & 45 \\
ssDNA-cellulose & 4.9 & 2255 & 461 & 7.7 & 820 & 168 & 17 \\
\hline \multicolumn{1}{c}{ a2 } & & & & & & & \\
Phosphocellulose & 89 & 18863 & 213 & 65 & 501 & 5.7 & 10 \\
DEAE-cellulose & 31 & 9720 & 314 & 33 & 59 & 1.9 & 1.2 \\
ssDNA-cellulose & 7.6 & 3255 & 427 & 11 & 5.7 & 0.7 & 0.1 \\
\hline
\end{tabular}

DNA polymerase $\alpha$ and primase activities were assayed as described under MATERIALS AND METHODS. One unit of activity is defined as the amount catalyzing the incorporation of $1 \mathrm{nmol}$ of dXTP into acid-insoluble materials in $1 \mathrm{~h}$ at $37^{\circ} \mathrm{C}$ for DNA polymerase activity and $1 \mathrm{nmol}$ of labeled dAMP for primase activity.

as single peaks at 8.2 and $6.4 \mathrm{~S}$, respectively. It must be noted that the sedimentation profile of the primase activity coincided well with that of the DNA polymerase activity in the case of the $a 1$ fraction, and almost no primase activity was detected in the $a 2$ fraction (Fig. 3). A summary of a typical purification experiment for DNA polymerase $\alpha 1$ and $\alpha 2$ is shown in Table 1 .

Characterization of de novo synthesis. Primase activity was assayed indirectly by measuring the incorporation of dAMP in the presence of ATP with poly(dT) as
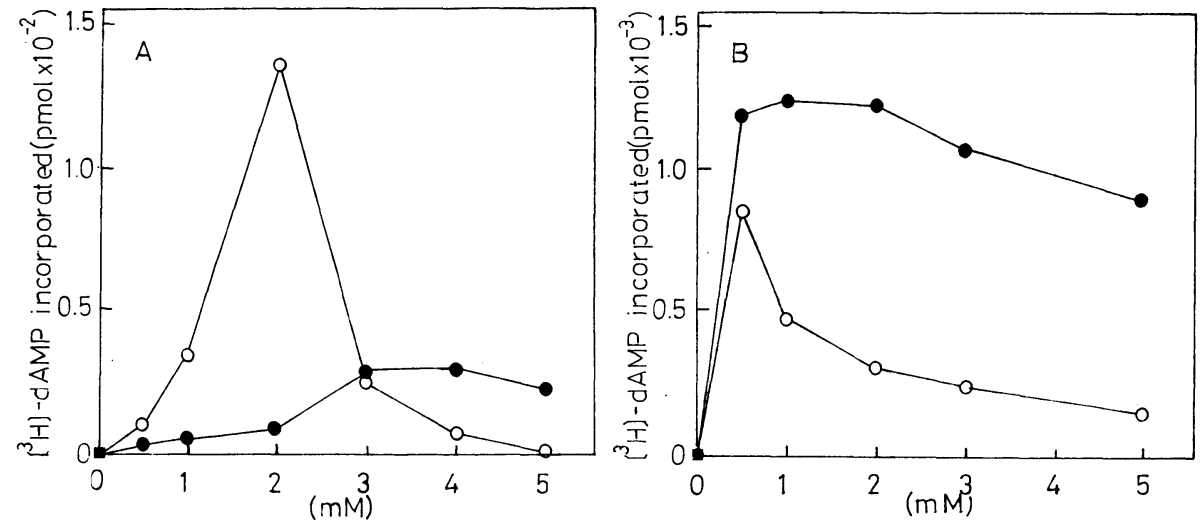

Fig. 4. (A) Effect of divalent cations on the primase activity. DNA primase activity was assayed in the primase assay mixture which contained $42 \mu \mathrm{g} / \mathrm{ml}$ poly(dT) and $2 \mathrm{mM}$ ATP in the presence of various concentrations of $\mathrm{MnCl}_{2}(\bigcirc)$ or $\mathrm{MgCl}_{2}(\bullet)$. (B) Effect of divalent cations on the DNA polymerase activity with poly $(\mathrm{dT}) \cdot(\mathrm{rA})_{10}$ as template-primer. DNA polymerase activity was assayed in the presence of various concentrations of $\mathrm{MnCl}_{2}(\bigcirc)$ or $\mathrm{MgCl}_{2}(\odot)$ under the same conditions as the primase assay except that $2 \mathrm{mM}$ ATP was omitted and $8.4 \mu \mathrm{g} / \mathrm{ml}(\mathrm{rA})_{10}$ was added. 


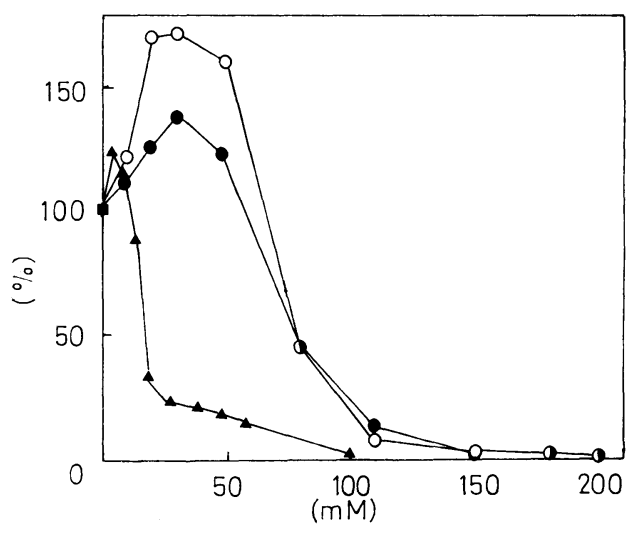

Fig. 5. Effect of salts on the primase activity. Assays were performed under the conditions for primase assay in the presence of the indicated concentrations of $\mathrm{KCl}(\bigcirc), \mathrm{NaCl}(\bullet)$, or $\left(\mathrm{NH}_{4}\right)_{2} \mathrm{SO}_{4}$ (A). In the absence of added salts, the assay mixture contained $3.3 \mathrm{mM} \mathrm{NaCl}$ that derived from the buffer in which $a 1$ was dissolved. One hundred percent of the activity corresponds to 631 pmol of dAMP incorporation.

template (de novo synthesis). Characterization of the assay system was performed with purified $\alpha 1$. The activity is absolutely dependent on the presence of ATP and a divalent cation. Fig. 4A shows the requirement of de novo synthesis for divalent cations in the presence of $2 \mathrm{mM}$ ATP. A sharp optimum is observed at $2 \mathrm{mM}$ with $\mathrm{Mn}^{2+}$, and a broad optimum at 3-4 mM with $\mathrm{Mg}^{2+} . \mathrm{Mn}^{2+}$ is much more effective than $\mathrm{Mg}^{2+}$, and 5-fold higher activity is observed with $\mathrm{Mn}^{2+}$ than with $\mathrm{Mg}^{2+}$ at their optimal concentrations. The above requirements are very different from those of DNA polymerase activity with poly $(\mathrm{dT}) \cdot(\mathrm{rA})_{10}$ as template-primer (Fig. 4B). Fig. 5 shows the salt requirements of de novo synthesis. The optimal concentrations of $\mathrm{KCl}$, $\mathrm{NaCl}$, and $\left(\mathrm{NH}_{4}\right)_{2} \mathrm{SO}_{4}$ are 30,30 , and $5 \mathrm{mM}$, respectively. Potassium chloride is the most effective among the salts tested. The activity is very sensitive to $\left(\mathrm{NH}_{4}\right)_{2} \mathrm{SO}_{4}$.

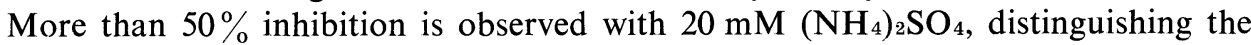
activity from known eukaryotic RNA polymerase activities. The sensitivity to $\left(\mathrm{NH}_{4}\right)_{2} \mathrm{SO}_{4}$ is very similar to that of the free primase reported by Tseng and Ahlem (21).

The reaction performed under optimal conditions continued linearly for up to 90 min with no lag period. The dose response curve of de novo synthesis was sigmoidal, suggesting that the reaction may involve the participation of two or more distinct proteins (not shown).

Comparison of the two forms of DNA polymerase $\alpha$. The effect of various inhibitors on the activities of DNA polymerase $\alpha 1$ and $\alpha 2$ was investigated. The activities of $\alpha 1$ and $\alpha 2$ are inhibited in a similar manner by NEM and araCTP (Fig. 6A, 6B). Both activities are almost completely inhibited by $5 \mathrm{mM}$ NEM. AraCTP inhibits $a 1$ and $a 2$ by $89 \%$ and $94 \%$, respectively, at $1 \mathrm{mM}$. Aphidicolin also inhibited both activities (Fig. 6C).

Table 2 shows the template-primer preferences of the two forms. Both forms prefer activated DNA and poly $(\mathrm{dT}) \cdot(\mathrm{rA})_{10}$ and exhibit low activity with heat-denatured DNA, native DNA, poly[d(A-T)], and poly $(\mathrm{dT}) \cdot(\mathrm{dA})_{12-18}$. Relatively high activity is 


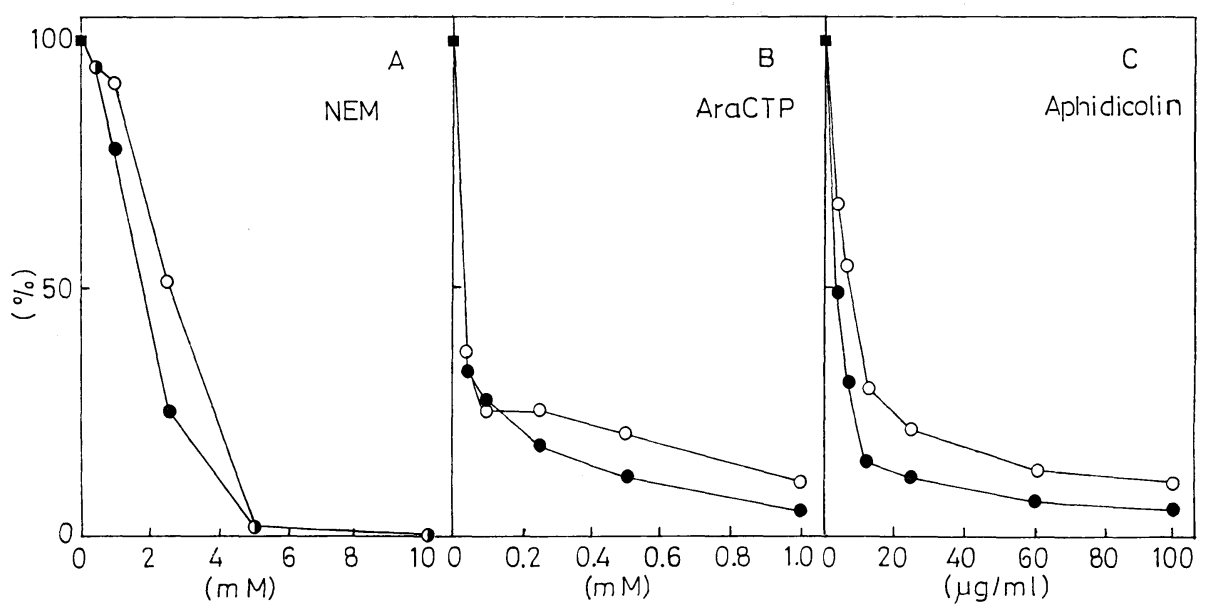

Fig. 6. Effect of various inhibitors on the activities of DNA polymerase $\alpha 1$ and $\alpha 2.663$ units of $\alpha 1(\bigcirc)$ and 673 units of $\alpha 2(\bullet)$ were assayed for DNA polymerase activity in the presence of various concentrations of inhibitors. (A) N-ethylmaleimide, (B) AraCTP, (C) Aphidicolin.

obtained by both forms with poly(dA)·(dT) ${ }_{12-18}$. No significant difference in templateprimer is observed between the two forms except that $a 1$ uses poly $(\mathrm{dT}) \cdot(\mathrm{rA})_{10}$ slightly more efficiently than $a 2$. The major difference observed between the two forms is in their S values, 8.2 and $6.4 \mathrm{~S}$ for $\alpha 1$ and $\alpha 2$, respectively (Fig. 3).

Tight association of primase with DNA polymerase $\alpha$. As described in the previous section, primase activity co-sedimented with DNA polymerase activity in a glycerol gradient which contained $0.3 \mathrm{M} \mathrm{KCl}$, indicating the tight association of the primase with DNA polymerase $\alpha 1$. We next tried to dissociate the primase from the DNA polymerase. DNA polymerase $\alpha 1$ was treated with $2 \mathrm{M}$ urea or $1 \mathrm{M} \mathrm{KCl}$ and sedimented through a glycerol gradient containing $2 \mathrm{M}$ urea or $1 \mathrm{M} \mathrm{KCl}$. The primase

TABLE 2. TEMPLATE-PRIMER PREFERENCE OF DNA POLYMERASE $a 1$ AND $a 2$

\begin{tabular}{lcc}
\hline \multicolumn{1}{c}{ Template-primer } & $a 1$ & $\alpha 2$ \\
\hline & pmol $(\%)$ & pmol $(\%)$ \\
\hline Activated DNA & $616(100)$ & $463(100)$ \\
Heat-denatured DNA & $11(1.8)$ & $8(2)$ \\
Native DNA & $26(4.2)$ & $12(2.6)$ \\
Poly[d(A-T)] & $8(1)$ & $15(3.2)$ \\
Poly $(\mathrm{dT}) \cdot(\mathrm{rA})_{10}$ & $907(147)$ & $480(104)$ \\
Poly $(\mathrm{dT}) \cdot(\mathrm{dA})_{12-18}$ & $30(4.9)$ & $8(2)$ \\
Poly $(\mathrm{dA}) \cdot(\mathrm{dT})_{12-18}$ & $103(17.0)$ & $81(17)$ \\
\hline
\end{tabular}

Fifteen micrograms of activated, heat-denatured, native DNA, and $1.25 \mu \mathrm{g}$ of the synthetic polymers were used. DNA polymerase activity with activated, heat-denatured, or native DNA was assayed by the $a$ assay system as described under MAterials and Methods. The activities with the synthetic polymers were assayed under the conditions of the $a$ assay except that the nucleoside triphosphates in the reaction mixture were changed as follows: $50 \mu \mathrm{M}\left[{ }^{3} \mathrm{H}\right]$-dTTP $(0.1 \mathrm{Ci} / \mathrm{mmol})$ and $50 \mu \mathrm{M}$ dATP for poly[d(A-T)], $50 \mu \mathrm{M}\left[{ }^{3} \mathrm{H}\right]-\mathrm{dATP}(0.1 \mathrm{Ci} / \mathrm{mmol})$ for poly $(\mathrm{dT})$. $(\mathrm{rA})_{10}$ and poly $(\mathrm{dT}) \cdot(\mathrm{dA})_{12-18}, 50 \mu \mathrm{M}\left[{ }^{3} \mathrm{H}\right]-\mathrm{dTTP}(0.1 \mathrm{Ci} / \mathrm{mmol})$ for poly $(\mathrm{dA}) \cdot(\mathrm{dT})_{12-18}$. 
activity was assayed in the presence of 0.3 units of $E$. coli DNA polymerase I. Under these conditions, the primase still co-sedimented with the DNA polymerase activity. Exposure of $a 1$ to more severe conditions such as $3 \mathrm{M}$ urea resulted in the loss of both enzyme activities.

\section{DISCUSSION}

In this study, we have partially purified two forms of DNA polymerase $\alpha$, one of which is associated with a primase activity, from FM3A cells. The two forms showed almost the same properties as DNA polymerase $a$ in their sensitivity to several inhibitors and their preference for template-primers except that al preferred poly$(\mathrm{dT}) \cdot(\mathrm{rA})_{10}$ slightly more than $a 2 \mathrm{did}$. The major difference between the two forms was observed in their sedimentation coefficients in glycerol gradients. The above observations seem to suggest the possibility that $\alpha 1$ consists of $\alpha 2$ and the primase. However, attempts to dissociate the primase from DNA polymerase $\alpha 1$ by treatment with $1 \mathrm{M} \mathrm{KCl}$ or $2 \mathrm{M}$ urea were not successful. Kaguni et al. (7) reported the separation of the primase from Drosophila DNA polymerase $\alpha$ in $\alpha$ glycerol gradient containing $2.8 \mathrm{M}$ urea after the treatment of the enzyme with $3.4 \mathrm{M}$ urea. We also tried to dissociate the primase from $\alpha 1$ under the same conditions but we could not detect primase and DNA polymerase activities under such severe conditions. Recently Tseng and Ahlem (21) have reported that primase which is not associated with DNA polymerase activity can be purified from mouse hybridoma cells by using a medium which contains $20 \%$ dimethylsulfoxide, $10 \%$ ethylene glycol, and $0.01 \%$ Nonidet P-40. Experiments to determine the conditions for dissociating and reconstituting the FM3A DNA polymerase $\alpha$-primase complex are now in progress.

The primase activity reported here was assayed indirectly by measuring ATPdependent DNA synthesis with poly(dT) as template. It is reported that a factor that greatly stimulates primase activity exists in Ehrlich ascites tumor cells, and that in the absence of the factor it is very hard to detect primase activity $(25,26)$. The attempts to detect such a factor in FM3A cells have not succeeded yet. However, even in the absence of the stimulating factor, we could easily detect primase activity. The primary reason for this easy detection may be the assay system used here, although the possibility that a stimulating factor is co-purified with al cannot be excluded completely.

The reaction mixture used here for primase assay contained $\mathrm{Mn}^{2+}$ instead of $\mathrm{Mg}^{2+}$, and 5-fold higher activity was observed with $\mathrm{Mn}^{2+}$ than with $\mathrm{Mg}^{2+}$ at their optimal concentrations. This preference for $\mathrm{Mn}^{2+}$ may be primarily due to the properties of the primase because in the presence of primer, $(\mathrm{rA})_{10}$, the levels of DNA polymerase activity of $\alpha 1$ in the presence of $\mathrm{Mg}^{2+}$ are higher than in the presence of $\mathrm{Mn}^{2+}(\mathrm{Fig}$. $4 \mathrm{~B})$. In addition, the sensitivity of the primase assay system to $\left(\mathrm{NH}_{4}\right)_{2} \mathrm{SO}_{4}$ may also be due to the properties of the primase itself because similar sensitivity is observed with primase which is not associated with DNA polymerase $a(21)$. Therefore, the system using poly(dT) and $\mathrm{Mn}^{2+}$ is very useful for the detection of primase activity.

It has been suggested from several lines of evidence that the primase associated with DNA polymerase $a$ is responsible for the synthesis of RNA primers of Okazaki fragments. In previous studies with HeLa cells, we suggested that HeLa nuclei contained two forms of DNA polymerase $a$, form I and form II, and that form I was responsible for the synthesis of Okazaki fragments $(3,4)$. At present it is not clear how $\alpha 1$ and $\alpha 2$ 
of FM3A cells correspond to form I and form II of HeLa cells. This question is currently under investigation.

Acknowledgements. This study was supported in part by a Grant-in-Aid for Scientific Research and a Grant-in-Aid for Cancer Research from the Ministry of Education, Science, and Culture, Japan.

\section{REFERENCES}

1. Aposhian, C.M. and A. Kornberg. Enzymatic synthesis of deoxyribonucleic acid. IX. The polymerase found after T2 bacteriophage infection of Escherichia coli. A new enzyme. J. Biol. Chem. 237, 519-529, 1962

2. Conaway, R.C. and I.R. Lehman. A DNA primase activity associated with DNA polymerase $\alpha$ from Drosophila melanogaster embryos. Proc. Natl. Acad. Sci. U.S.A. 79, 2523-2527, 1982

3. Enomoto, T., S. TANuma and M. Yamada. Characterization of deoxyribonucleic acid synthesis in reconstituted nuclear systems. Biochemistry 22, 1128-1133, 1983

4. Enomoto, T., S. Tanuma and M. Yamada. Purification and characterization of two forms of DNA polymerase $\alpha$ from HeLa cell nuclei. Biochemistry 22, 1134-1138, 1983

5. Gronostajski, R.M., J. Field and J. Hurwitz. Purification of a primase activity associated with DNA polymerase $a$ from HeLa cells. J. Biol. Chem. 259, 9479-9486, 1984

6. Hanaoka, F., K. Nagata, Y. Watanabe, T. Enomoto and M. Yamada. Accumulation of $\mathrm{S}$ phase populations of FM3A cells growing in the mouse due to administration of 5-fluoro2'-deoxyuridine. Cell Struct. Funct. 6, 357-365, 1981

7. Kaguni, L.S., J.-M. Rossignal, R.C. Conaway, G.R. Banks and I.R. Lehman. Association of DNA primase with the $\beta / \gamma$ subunits of DNA polymerase a from Drosophila melanogaster embryos. J. Biol. Chem. 258, 9037-9039, 1983

8. Kawasaki, K., K. Nagata, T. Enomoto, F. Hanaoka and M. Yamada. Detection of two factors stimulating DNA polymerase $a$ activity on heat denatured DNA from mouse FM3A cells. Biochem. Internat. 5, 121-128, 1982

9. Kawasaki, K., K. Nagata, T. Enomoto, F. Hanaoka and M. Yamada. Purification and characterization of a factor stimulating DNA polymerase $a$ activity from mouse FM3A cells. J. Biochem. 95, 485-493, 1984

10. Lindell, T.J., F. Weinberg, P.W. Morris, R.G. Roeder and W.J. Rutter. Specific inhibition of nuclear RNA polymerase II by $\alpha$-amanitin. Science 170, 447-449, 1970

11. Nishimura, M., H. Yasuda, S. Ikegami, M. Ohashi and M. Yamada. Aphidicolin resistant mutant of which polymerase $\alpha$ is induced by this drug. Biochem. Biophys. Res. Commun. 91, 939-945, 1979

12. Nishizawa, M., K. Tanabe, A. Matsukage, H. Nakamura and T. Yagura. Detection of DNA replicase activity in rat thymoma cells. J. Biochem. 93, 287-290, 1983

13. Ono, Y., T. Enomoto, F. Hanaoka and M. Yamada. Separation of two forms of HeLa DNA polymerase $a$ with different binding affinity to DNA. Gann 69, 207-212, 1978

14. Ono, Y., T. Enomoto and M. Yamada. Variation of two forms of DNA polymerase $a$ during a HeLa cell cycle. Gann 70, 529-532, 1979

15. Plevani, P., G. Badaracco, C. Augl and L.M.S. Chang. DNA polymerase I and DNA primase complex in yeast. J. Biol. Chem. 259, 7532-7539, 1984

16. Shioda, M., E.M. Nelson, M.L. Bayne and R.M. Benbow. DNA primase activity associated with DNA polymerase $a$ from Xenopus laevis ovaries. Proc. Natl. Acad. Sci. U.S.A. 79, 72097213,1982

17. Tanuma, S., T. Enomoto and M. Yamada. Characterization of DNA synthesis in salt-treated HeLa cell nuclei. Cell Struct. Funct. 5, 27-37, 1980

18. Tawaragi, Y., T. Enomoto, Y. Watanabe, F. Hanaoka and M. Yamada. Multiple deoxyribonucleic acid dependent adenosinetriphosphatases in FM3A cells. Characterization of an adenosinetriphosphatase that prefers poly[d(A-T)] as cofactor. Biochemistry 23, 529-533, 1984 
19. Tsai, Y.-J., F. Hanaoka, M.M. Nakano and M. Yamada. A mammalian DNA ${ }^{-}$mutant decreasing nuclear DNA polymerase $a$ activity at nonpermissive temperature. Biochem. Biophys. Res. Commun. 91, 1190-1195, 1979

20. TSENG, B.Y. and C.N. AHLEM. DNA primase activity from human lymphocytes. Synthesis of oligoribonucleotides that prime DNA synthesis. J. Biol. Chem. 257, 7280-7283, 1982

21. Tseng, B.Y. and C.N. Ahlem. A DNA primase from mouse cells. Purification and partial characterization. J. Biol. Chem. 258, 9845-9849, 1983

22. WANG, T.S.-F., S.-Z. Hu and D. KORN. DNA primase from KB cells. Characterization of a primase activity tightly associated with immunoaffinity-purified DNA polymerase $\alpha . J$. Biol. Chem. 259, 1854-1865, 1984

23. Watanabe, Y., K. Nagata, Y. Tawaragi, T. Enomoto, F. Hanaoka and M. Yamada. DNA-dependent ATPase B of FM3A cells. Its separation from DNA polymerase $\alpha$. FEBS Lett. 149, 44-46, 1982

24. Weissbach, A. Eukaryotic DNA polymerases. Annu. Rev. Biochem. 46, 25-47, 1977

25. Yagura, T., T. Kozu and T. Seno. Mouse DNA polymerase accompanied by a novel RNA polymerase activity: Purification and partial characterization. J. Biochem. 91, 607-618, 1982

26. Yagura, T., T. Kozu, T. Seno, M. Saneyoshi, S. Hiraga and H. Nagano. Novel form of DNA polymerase $a$ associated with DNA primase activity of vertebrates. Detection with mouse stimulating factor. J. Biol. Chem. 258, 13070-13075, 1983

27. Yasuda, H., Y. Matsumoto, S. Mita, T. Marunouchi and M. Yamada. A mouse temperaturesensitive mutant defective in $\mathrm{H} 1$ histone phosphorylation is defective in deoxyribonucleic acid synthesis and chromosome condensation. Biochemistry 20, 4414-4419, 1981

28. Yoshida, S., R. Suzuki, S. Masaki and O. Koiwai. DNA primase associated with 10 S DNA polymerase $a$ from calf thymus. Biochim. Biophys. Acta 741, 348-357, 1983

(Received for publication, April 4, 1985) 